\title{
ARTIKRELIT
}

Elina Heininen, Sakari Siilin \& Tarja Valkonen

\section{Huumori työnohjaajan ja ohjattavan vuorovaikutuksessa}

\begin{abstract}
Abstrakti
Huumori ilmenee työelämän interpersonaalisessa vuorovaikutuksessa eri tavoin, ja sillä on monia merkittäviä vuorovaikutusfunktioita. Huumorin on havaittu muun muassa edistävän yhteistyöhalukkuutta ja avoimuutta. Tässä tutkimuksessa tarkastelemme työnohjaajan ja ohjattavan vuorovaikutuksessa ilmenevää huumoria. Tutkimusotteemme on laadullinen, ja menetelmänä käytämme vuorovaikutusanalyysia. Aineisto koostuu kolmesta työnohjaustapaamisesta. Tulokset osoittavat, että huumori auttaa työnohjaajaa ja ohjattavaa hallitsemaan ammatillisen vuorovaikutussuhteensa jännitteitä. Työnohjauksessa huumoria ilmaistaan usein vuorovaikutusosapuolia yhdistävällä tavalla, minkä voidaan ajatella tukevan työnohjaajan ja ohjattavan yhteistyötä. Huumorin avulla vuorovaikutusosapuolet pyrkivät hallitsemaan työnohjaustilanteen kuormittavuutta, joka liittyy muun muassa henkilökohtaisista ja arkaluontoisista asioista keskustelemiseen. Tulokset auttavat ymmärtämään yksilötyönohjauksen vuorovaikutusta ja siinä ilmenevän huumorin merkitystä erityisesti ohjaussuhteen ja työnohjauksen tavoitteiden kannalta.
\end{abstract}

\section{Johdanto}

Tässä artikkelissa tarkastelemme huumoria yksilötyönohjauksessa. Yksilötyönohjauksen osapuolia ovat työnohjaaja ja ohjattava, ja ohjaus rakentuu heidän keskinäisessä vuorovaikutuksessaan. Yksilötyönohjauksessa keskiössä on ohjattava ja hänen työnsä. Tapaamisissa korostuu nimenomaan ohjaajan ja ohjattavan interpersonaalinen vuorovaikutus. (Alhanen ym. 2016, 132.)

Esimerkiksi Vehviläinen $(2000,227)$ on luonnehtinut ohjauskeskustelua institutionaaliseksi vuorovaikutukseksi, jossa osapuolet tietävät, että ohjauksessa käsitellään nimenomaan tiettyjä asioita, tietyssä tarkoituksessa. Työnohjauksessa osapuolet sopivat yhteisistä tavoitteista ja ohjauksen kestosta. Ohjauksen tarkoituksena on tarkastella, arvioida ja kehittää ohjattavan työntekoa ja ammatillisia valmiuksia, edistää ammatillista oppimista ja sujuvoittaa työntekoa ohjattavan jatkuvan itsearvioinnin ja palautteensaannin avulla. (Kankaanranta 2008, 15; Paunonen-Ilmonen 2001, 64; Työnohjaus 2019.)

Työnohjaajan ja ohjattavan ammatillinen suhde määritellään tässä sopimuksenvaraiseksi, tavoitteelliseksi ja jännitteiseksi vuorovaikutussuhteeksi, jossa osapuolet pyrkivät edistämään ohjattavan jaksamista ja valmiuksia työssä. Osapuolten odotetaan keskittyvän pääasiallisesti työhön liittyviin asioihin ja säilyttävän tietynlaisen etäisyyden toisiinsa (Paunonen-Ilmonen 2001, 101). Toisaalta tarvitaan riittävää läheisyyttä, jotta osapuolten välille voi syntyä luottamusta ja ohjattava kokee voivansa kertoa henkilökohtaisista asioistaan.

Huumorin on havaittu monissa ammatillisissa vuorovaikutussuhteissa edistävän vuoro- 
vaikutusta sekä tukevan asiakkaan aktiivisuutta, hyvinvointia ja itseymmärrystä (ks. esim. Bolkan \& Goodboy 2015; Gladding \& Drake Wallace 2016, 3; Goodboy ym. 2015; Scholl 2007; Simmons-Mackie \& Schultz 2003). Toisaalta huumori on aina tilannesidonnainen ja monitulkintainen ilmiö, jolla voi olla myös kielteisiä seurauksia, jos huumori esimerkiksi ymmärretään väärin tai se on tilanteeseen sopimatonta (Lynch 2002, 430). Huumori voi olla keino ilmaista ja ylläpitää valtasuhteita ja heijastua siten kielteisesti vuorovaikutussuhteeseen ja oikeuttaa epätasa-arvon tai vallankäytön (Holmes 2000; Vuorela 2005). Osapuolet joutuvatkin vuorovaikutuksessa neuvottelemaan siitä, mikä milloinkin on tilanteeseen sopivaa huumoria.

Tavoitteenamme on kuvata ja ymmärtää huumoria työnohjaajan ja ohjattavan vuorovaikutussuhteessa. Tarkastelun kohteena on erityisesti se, millä tavalla huumori ilmentää ohjaajan ja ohjattavan ammatillista vuorovaikutussuhdetta ja mikä merkitys huumorilla on työnohjauksen tavoitteiden kannalta.

\section{Työnohjaajan ja ohjattavan vuorovaikutussuhde}

Työnohjaajan ja ohjattavan suhdetta voidaan tarkastella ammatillisena vuorovaikutussuhteena. Ammatillisissa vuorovaikutussuhteissa osapuolet ovat sitoutuneet vuorovaikutukseen toistensa kanssa, ja heillä on vakiintuneet tavat olla kanssakäymisessä. Näille suhteille ominaista on tehtäväkeskeisyys, tavoitteellisuus ja osapuolten tietoisuus suhteen jatkuvuudesta tai kestosta. (Guerrero, Andersen \& Afifi 2011, 7; Sias 2009, 2.)

Ammatillisia vuorovaikutussuhteita on jäsennetty monella eri tavalla. Tässä työnohjaajan ja ohjattavan ammatillista vuorovaikutussuhdetta tarkastellaan nimenomaan interpersonaallisena suhteena relationaalisen dialektiikan teorian (Baxter \& Montgomery 1996) näkökulmasta. Teorian mukaan vuorovaikutussuhteet ovat aina jännitteisiä. Suhteen si- säiset jännitteet ilmentävät suhteen osapuolten erilaisia, usein vastakkaisiakin tavoitteita ja odotuksia esimerkiksi vuorovaikutussuhteen luonteesta. Nämä tavoitteet ja odotukset puolestaan heijastuvat vuorovaikutukseen kilpailevina diskursseina. (Baxter \& Norwood 2015, 279-281.) Jännitteet ovat vuorovaikutussuhteissa luonnollisia ja väistämättömiä, eikä niitä voi pitää ristiriitoina, jotka tulisi ratkaista. Pikemminkin jännitteet voidaan nähdä vuorovaikutusta luonnehtivina ja motivoivina tekijöinä, joita suhteissa aina on ja joita osapuolet pyrkivät jollain tavoin hallitsemaan. Jännitteet heijastuvat siihen, mitä vuorovaikutussuhteessa ilmaistaan, miten toisen osapuolen ilmauksia tulkitaan ja kuinka niihin reagoidaan.

Jännitteiden hallintaan ammatillisissa vuorovaikutussuhteissa liittyy olennaisesti suhteen asymmetrisyys. Asymmetrisissa suhteissa osapuolten valta-asema, auktoriteetti, asiantuntijuus tai osaaminen ovat epätasapainossa (Puutio, Kykyri \& Wahlström 2008, 35-40). Osapuolten eriytyneet roolit ja velvollisuudet sekä eriävät odotukset itseä ja toista kohtaan kytkeytyvät tapaan hallita suhteen sisäisiä jännitteitä. Työnohjauksessa suhteen a-symmetrisyys liittyy siihen, että ohjaajalla on asiantuntijarooli nimenomaan työnohjaajana sekä sen tuoma valta ja velvollisuus tukea ohjattavaa yhdessä asetettujen tavoitteiden saavuttamisessa (Alhanen ym. 2016, 132-133). Ohjattava puolestaan on työnsä lähtökohtien ja tavoitteiden asiantuntija. Työnohjauksessa hänen vastuullaan on kertoa itsestään, puhua työstään, altistaa se arvioinnille ja ottaa vastaan uusia näkökulmia. Molemmilla osapuolilla on vastuu toimia työnohjauksen käytänteiden mukaisesti.

Ammatillisissa vuorovaikutussuhteissa tunnusomaisia jännitteitä ovat emotionaalisuus sekä yksityisyys ja etäisyys (Gerlander \& Isotalus 2010). Tällaisessa vuorovaikutussuhteessa osapuolet joutuvat kohtaamaan, käsittelemään ja ylläpitämään sekä omia että toisen tunteita. Emotionaalisuuden jännitteen hallitseminen edellyttää osapuolten sopimus- 
ta siitä, kuinka ja mitä tunteita vuorovaikutuksessa ilmaistaan. Alhasen ja kumppaneiden $(2016,133)$ mukaan työnohjaajan tulee ylläpitää ammatillista neutraaliutta, mikä asettaa hänen omalle tunneilmaisulleen rajoituksia. Ohjaajan odotetaan vastaavan ohjattavan tunteisiin ottamalla ne vakavasti ja osoittamalla välittämistä, mutta toisaalta toimimaan ikään kuin peilinä, jotta ohjattava pystyy itse hahmottamaan tilanteensa ja toimintavaihtoehtonsa. Työnohjauksessa emotionaalisen jännitteen voidaan ajatella näkyvän erityisesti siinä, miten huumoria ilmaistaan ja kuinka siihen reagoidaan.

Yksityisyyden jännite haastaa ammatillisen vuorovaikutussuhteen osapuolia ratkaisemaan, mitä he haluavat kertoa itsestään, mitä salata ja minkälaisen kuvan he itsestään luovat. Etäisyyden jännitteeseen puolestaan kytkeytyvät odotukset ja näkemykset vuorovaikutussuhteen luottamuksellisuudesta ja välittömyydestä sekä osapuolten valtasuhteista. Työnohjauksessa yksityisyyden jännite voi ilmetä esimerkiksi siinä, miten ohjattava paljastaa henkilökohtaisia tietoja itsestään, työyhteisöstään ja työstään. Sen sijaan työnohjaajalla on vastuu suhtautua ohjattavaan riittävän objektiivisesti työnohjauksen tavoitteiden saavuttamiseksi. Tämän takia työnohjaajia neuvotaankin huolehtimaan suhteen rajojen määrittämisestä ja varjelemisesta (Alhanen ym. 2016, 132). Oman yksityisyyden sääteleminen vaatii riittävän etäisyyden säilyttämistä ohjattavaan. Toisaalta työnohjauksen luottamuksellisuus sekä ohjattavan itsestäkertominen ja emotionaalisesti kuormittavien asioiden käsittely edellyttävät suhteen läheisyyttä.

Huumori kuvastaa vuorovaikutussuhteen luonnetta ja on merkittävä tekijä myös vuorovaikutussuhteen jännitteiden hallinnassa. Huumoria työelämän interpersonaalisissa suhteissa on tutkittu jonkin verran, ja esimerkiksi terapiasuhteissa sen on havaittu edistävän osapuolten yhteistyötä ja keskinäistä luottamusta (Dziegielewski ym. 2003, 74-75).

\section{Huumori vuorovaikutusilmiönä}

Huumori on intentionaalinen tai epäintentionaalinen ilmaus, joka on tarkoitettu tai joka tulkitaan hauskaksi eli joka herättää vuorovaikutusosapuolissa huvittuneisuutta. Huumoria voidaan ilmaista niin kielellisesti kuin nonverbaalisestikin. (Holmes 2000, 163; Lynch 2009, 480.) Huumori voi ilmetä esimerkiksi nauramisena tai hymyilemisenä. Huumoria ei kuitenkaan pidä sekoittaa nauruun, vaikka sitä voi esiintyä humoristisen ilmauksen yhteydessä (Foot \& McCreaddie 2006, 307). Huumori ja nauru voivat joskus palvella samaa tarkoitusta (esim. jännittyneisyyden vähentämistä) Naurua voi kuitenkin ilmetä myös silloin, kun huumoria ei ole ilmaistu (Foot \& McCreaddie 2006, 307-308; Kangasharju \& Nikko 2009, 103). Huvittuneisuus puolestaan voi ilmetä myös ilman naurua esimerkiksi silloin, kun vitsailuun vastataan toisella vitsillä.

Huumoria voidaan ilmaista eri tyyleillä. Huumorityylit ovat osittain tilannesidonnaisia, koska ilmaisutavat liittyvät usein vuorovaikutustilanteen ominaispiirteisiin, kuten käsiteltäviin aiheisiin ja tilanteen tavoitteisiin. Huumori, joka sopii tyyliltään läheisiin vuorovaikutussuhteisiin, voidaan työelämän ammatillisissa suhteissa tulkita sopimattomaksi.

Romeron ja Cruthirds (2006) jäsentävät huumorityylit viiteen luokkaan kuvailemalla huumorin ilmaisijan vuorovaikutuskäyttäytymistä. Vuorovaikutusosapuolia yhdistävä huumorityyli ilmenee rauhallisina, vuorovaikutusta edistävinä kielellisinä tai nonverbaalisina ilmaisuina, jotka voivat olla esimerkiksi sisäpiirivitsailua tai hyväntahtoista leikittelyä, naurua, huvittavia eleitä tai ilmeitä. Tällä tavoin huumoria ilmaiseva henkilö voi vähentää muun muassa itsensä ja vuorovaikutusosapuoltensa välistä jännittyneisyyttä, kehittää vuorovaikutussuhdetta ja luoda positiivista ilmapiiriä. Huumorin ilmaisijaa voimauttava huumori kohdistuu usein enemmän itseen kuin muihin. Tällainen huumori auttaa hallitsemaan kuormittavia tilanteita, rakentamaan itseluottamusta ja vahvistamaan myönteisiä tunteita. 
Aggressiivisella huumorityylillä puolestaan pyritään manipuloimaan, alistamaan, pilkkaamaan tai saattamaan toiset naurunalaisiksi. Tällainen huumori korostaa huumorin ilmaisijan paremmuutta suhteessa toisiin. Lievästi aggressiivinen huumorityyli on nimensä mukaisesti aggressiivista huumoria lievempää, ja sillä voi olla myös vuorovaikutusta edistäviä vaikutuksia. Esimerkiksi vitsailevalla piikittelyllä huumorin ilmaisija voi osoittaa erimielisyyttä ilman, että toinen osapuoli reagoi siihen kielteisesti. Itseironiaa ilmaistessaan henkilö pilkkaa ja vähättelee itseään vitsaillen omalla kustannuksellaan pyrkimyksenään viihdyttää toisia ja saada hyväksyntää. Itseironisen huumorin avulla henkilö voi myös yrittää tehdä itsestään helpommin lähestyttävän. (Romero \& Cruthirds 2006, 59-60.)

Huumorityylejä ammatillisessa vuorovaikutussuhteessa on tutkittu jonkin verran muun muassa tarkastelemalla puheterapeutin ja asiakkaan vuorovaikutusta. SimmonsMackie ja Schultz (2003) havaitsivat, että huumorityylit olivat luonteeltaan rakentavia sekä puheterapeutin ja asiakkaan vuorovaikutusta sujuvoittavia. Ne edistivät yhteistyötä ja terapiaprosessia.

Huumori on usein strategista, ja sitä käytetään eri tarpeisiin (Holmes 2000; Vuorela 2005). Huumoria voidaan lähestyä myös vuorovaikutusfunktioiden näkökulmasta, jolloin tarkastellaan nimenomaan sitä, millaisia osapuolten viestintätarpeita huumori toteuttaa. Huumorin vuorovaikutusfunktioita on jäsennetty eri tavoin. Esimerkiksi Lynch $(2002,431)$ nimeää huumorin vuorovaikutusfunktioiksi kiusaamisen, viihdyttämisen, huomion hakemisen ja vaikuttamisen. Footin ja McCreaddien (2006, 299-306) mukaan huumorilla voi olla myös tiedon hakemisen ja jakamisen funktio. Vitsailemalla voidaan esimerkiksi selvittää omaa asemaa ja suosiota ryhmässä tai vihjailla peitellysti jotain, mitä ei haluta sanoa suoraan. Huumorilla pyritään hallitsemaan vuorovaikutusta niin interpersonaalisella kuin ryhmän tasolla. Tällöin huumori voi sujuvoittaa keskusteluaiheen vaihtoa. Huumorin avul- la voidaan myös huolehtia vuorovaikutussuhteiden ylläpidosta ja kehittämisestä. Graham, Papa ja Brooks (1992) ovat jäsentäneet huumorin vuorovaikutusfunktioita peräti $24 \mathrm{ka}-$ tegoriaan. Huumorilla voi olla vaikean asian esiintuomisen, mielialan ilmaisemisen, puolus tautumisen, pidättyväisyyden sekä vuorovaikutusosapuolen kontrolloinnin funktiot.

Huumorilla voi siis olla sekä myönteisiä (esim. ahdistuneisuuden vähentämisen) että kielteisiä (esim. vallankäytön, manipuloinnin, toisten halventamisen ja nöyryyttämisen) tarkoitusperiä. Työnohjaajan ja ohjattavan suhteen kaltaisissa ammatillisissa vuorovaikutussuhteissa huumorin on todettu usein vaikuttavan myönteisesti. On esimerkiksi havaittu, että opettajan huumori voi edistää opiskelijoiden aktiivisuutta, työpanosta, omaehtoisuuden ja yhteisöllisyyden tunnetta sekä luoda myönteisiä mielikuvia ja lisätä vuorovaikutusosapuolen puoleensavetävyyttä (Bolkan \& Goodboy 2015; Dziegielewski ym. 2003; Goodboy ym. 2015; Wanzer, Frymier \& Irwin 2010). Huumori lisää terapiassa asiakkaan motivaatiota ja yhteistyöhalukkuutta (Simmons-Mackie \& Schultz 2003). Se voi tukea asiakkaan riskinotto- ja ongelmanratkaisukykyä, luovuutta ja oivallusmahdollisuuksia sekä vähentää myös terapeutin kuormitusta (Gladding 1995). Huumorin on todettu auttavan säätelemään kielteisiä tunteita (Samson \& Gross 2012).

Huumori näyttäisi lieventävän ammatillisissa vuorovaikutussuhteissa osapuolten jännittyneisyyttä, kuten kiusaantuneisuutta ja hämmennystä (Bolkan \& Goodboy 2015; Scholl 2007; Dziegielewski ym. 2003; SimmonsMackie \& Schultz 2003). Huumori voi edistää vuorovaikutustilanteen avointa ja luottamuksellista ilmapiiriä sekä auttaa löytämään uusia näkökulmia ongelmiin (Gladding 1995; Goodboy ym. 2015; Maples ym. 2001; Scholl 2007; Simmons-Mackie \& Schultz 2003.)

Työelämän huumoritutkimusta on kritisoitu siitä, että huumori on usein operationaalistettu ikään kuin välineeksi, jolla saavutetaan tiettyjä strategisia vuorovaikutustavoitteita, ja 
siitä, että sitä on tutkittu lähinnä mittaavilla menetelmillä (esim. Dziegielewski ym. 2003; Holmes 2000, 160; 2006, 29). Tässä tutkimuksessa huumoria tarkastellaan dynaamisena vuorovaikutusilmiönä, joka voi ilmetä lukuisin eri tavoin autenttisten ohjaustapaamisten vuorovaikutuksessa.

\section{Tutkimuksen toteuttaminen}

Tutkimuksen tavoitteena on kuvata ja ymmärtää huumoria työnohjaajan ja ohjattavan vuorovaikutuksessa. Huumoria tarkastellaan funktionaalisesta näkökulmasta, ja se määritellään sellaiseksi kielelliseksi tai nonverbaaliseksi ilmaukseksi, joka saa aikaan huvittuneisuutta joko huumorin ilmaisijassa, toisessa osapuolessa tai heissä molemmissa. Johdamme tutkimuksen tavoitteesta seuraavat tutkimuskysymykset:

1) Miten huumoria ilmaistaan, ja millaista se on tyyliltään työnohjauksen vuorovaikutuksessa?

2) Miten huumoriin työnohjauksessa reagoidaan?

3) Mitä vuorovaikutusfunktioita huumorilla on työnohjaajan ja ohjattavan vuorovaikutuksessa?

Aineisto koostuu kolmesta autenttisesta, videoidusta työnohjaustapaamisesta. Tilanteet videoitiin siten, että molemmat osapuolet näkyvät videossa kokonaan. Tämän ansiosta pystyttiin analysoimaan kielellisten sanomien lisäksi myös nonverbaalista viestintää.
Kahdessa tapaamisessa oli sama työnohjaaja mutta eri asiakkaat. Kolmas oli toisen työnohjaajan ja hänen asiakkaansa tapaaminen. Toisella työnohjaajalla oli pitkä työkokemus (13 vuotta), toinen viimeisteli työnohjaajakoulutustaan. Taulukosta 1 ilmenevät ohjaussuhteiden ja -tapaamisten kestot.

Työnohjauksessa käsitellään usein hyvinkin henkilökohtaisia ja arkaluonteisia asioita. Jotta videointi ei häiritsisi ohjaamistapaamista liikaa, sijoitettiin kamera mahdollisimman huomaamattomasti ohjaustilaan. Tutkimushenkilöt olivat tietoisia kuvaamisesta. Heiltä pyydettiin suullinen suostumus kuvaamiseen ja lupa käyttää tallennetta tutkimustarkoitukseen. Aineistoa säilytettiin salasanalla suojatusti. Aineiston raportoinnissa on varmennettu, ettei aineistoesimerkeistä ole mahdollista tunnistaa henkilöitä.

Tarkastelemme vuorovaikutusanalyysin avulla, miten huumoria ilmaistaan, millaista se on tyyliltään, kuinka siihen reagoidaan sekä millaisia vuorovaikutusfunktioita huumori työnohjauksessa toteuttaa. Vuorovaikutusanalyysia voi toteuttaa monin tavoin, mutta yleisesti ottaen sillä pyritään ymmärtämään vuorovaikutuksessa ilmenevää toistuvuutta sekä vuorovaikutuksen ominaispiirteitä ja merkityksiä (Frey, Botan \& Kreps 2000, 243; Myers \& Seibold 2012, 340-341). Analyysi toteutettiin laadullisena sisällönanalyysinä, jossa aineistosta havaitut analyysiyksiköt eli huumorijaksot luokiteltiin osin teoria-, osin aineistolähtöisesti muodostettuihin luokkiin.

Aineiston käsittelyn ja analyysin vaiheet olivat seuraavat: 1) analyysiyksikön määrittäminen, 2) aineistoon tutustuminen, 3) havain-

TAULUKKO 1. Aineistona olevat ohjaustapaamiset

\begin{tabular}{|c|c|c|c|c|}
\hline Työnohjaus & Ohjaaja & $\begin{array}{c}\text { Ohjaussuhteen } \\
\text { kesto }\end{array}$ & $\begin{array}{c}\text { Tallennetun } \\
\text { ohjaustapaamisen } \\
\text { kesto minuutteina }\end{array}$ & $\begin{array}{c}\text { Ohjaustapaamisia } \\
\text { tutkimushetkeen } \\
\text { mennessä yhteensä }\end{array}$ \\
\hline 1. & A & $5 \mathrm{kk}$ & 54 & 5 \\
\hline 2. & B & $6 \mathrm{kk}$ & 64 & 5 \\
\hline 3. & B & $11 / 2 \mathrm{v}$ & 67 & 15 \\
\hline
\end{tabular}


nointitaulukon muodostaminen, 4) tulkintasääntöjen laadinta, 5) tallenteiden analysointi ja 6) tulosten kvantifiointi.

Analyysiyksikkönä oli huumorijakso. Jakso muodostui ilmauksesta ja siihen reagoinnista. Huumorijaksoksi määrittelimme sellaisen työnohjaajan ja ohjattavan vuorovaikutuksessa ilmenevän jakson, josta on selkeästi erotettavissa huumoria, eli jossa jonkin kielellisen tai nonverbaalisen ilmauksen yhteydessä vähintään toisen osapuolen vuorovaikutuskäyttäytymisestä oli havaittavissa huvittuneisuutta (nauramista tai hymyilemistä). Huumoriilmaus saattoi olla yksittäinen kielellinen tai nonverbaalinen ilmaus tai niitä laajempi ilmaisukokonaisuus. Huumorijakso saattoi alkaa toisen osapuolen huumori-ilmauksena, johon toinen reagoi tai oli reagoimatta humoristisesti. Toisaalta jakso saattoi myös alkaa puheenvuorona, jonka yhteydessä ei ilmaistu huvittuneisuutta millään tavoin, mutta johon toinen osapuoli kuitenkin reagoi jollain tavalla humoristisesti.

Toisessa vaiheessa tutustuimme aineistoon syvällisemmin. Tässä vaiheessa rajasimme analyysin ulkopuolelle sellaisen työnohjaajan ja ohjattavan vuorovaikutuksen, jossa ei keskusteltu työnohjauksen asioista. Tämä tarkoitti käytännössä esimerkiksi säästä puhumista ennen kuin osapuolet istuivat alas ja työnohjaaja aloitti ohjauksen kysymällä asiakkaan kuulumisia. Niin ikään rajasimme pois keskustelun, jota käytiin sen jälkeen, kun osapuolet olivat sanallistaneet tapaamisen päättyneeksi. Aineiston laajuus oli lopulta yhteensä 3 tuntia ja 6 minuuttia. Aineistosta analysoitiin yhteensä 102 huumorijaksoa.

Analyysin kolmannessa vaiheessa laadimme havainnointitaulukon pääosin teorialähtöisesti. Havainnointitaulukon laatimisessa hyödynsimme Romeron ja Cruthirdsin (2006) sekä Simmons-Mackien ja Schultzin (2003) jäsennyksiä huumorityyleistä sekä Grahamin, Papan ja Brooksin (1992) jäsennystä huumorin vuorovaikutusfunktioista. Lisäksi nostimme havainnointitaulukkoon luokan "huumoriin reagoiminen". Merkitsimme taulukkoon myös sen, mitä keskustelussa tapahtui ennen huumorijaksoa ja miten vuorovaikutusosapuolet jatkoivat keskustelua huumorijakson jälkeen. Merkitsimme havainnointitaulukkoon siis seuraavat seikat:

1) ajankohta, jolloin videoidusta ohjauskeskustelusta on havaittavissa huumorijakso

2) osapuoli, joka aloitti huumorijakson

3) ilmaistiinko huumori kielellisesti vai nonverbaalisesti

4) toisen osapuolen reaktio humoristiseen sanomaan tai reagoimatta jättäminen

5) lyhyt kuvaus siitä, mitä huumorijakson aikana tapahtui sekä tulkinta huumorityylistä

6) tulkinta siitä, mitä vuorovaikutusfunktiota huumori ilmensi

7) lyhyt kuvaus siitä, mitä keskustelussa ennen huumorijaksoa tapahtui

8) lyhyt kuvaus siitä, mitä huumorijakson jälkeen tapahtui

Analyysin neljännessä vaiheessa muodostimme tulkintasäännöt, joilla varmensimme analyysin yhteneväisyyden. Katsoimme ensin itsenäisesti yhden ohjaustallenteen ja koodasimme kaikista siinä ilmenneistä huumorijaksoista havainnointitaulukkoon sen, mikä huumorityyli ja mikä huumorin vuorovaikutusfunktio kulloinkin oli kyseessä. Merkitsimme jokaiseen huumorijaksoon yhden huumorityylin ja yhden huumorin vuorovaikutusfunktion. Tämän jälkeen tarkistimme havaintojemme yhteneväisyyden. Eroavaisuudet koskivat joitakin yksittäisiä tulkintoja siitä, mikä huumorinvuorovaikutusfunktio tai mikä huumorityyli oli kyseessä. Näiden osalta täsmensimme tulkintasääntöjä. Esimerkiksi vuorovaikutusosapuolen viihdyttämisen ja huumorintajun osoittamisen tulkinnoissa oli eroja, jolloin täsmensimme tulkintasääntöä. Tulkitsimme huumori-ilmauksen kuuluvan jompaankumpaan luokkaan sen perusteella, miten intentionaaliselta ilmaisu vaikutti. Vuorovaikutusosapuolen viihdyttämisen tulkitsimme silloin, kun huumorin tarkoituk- 
sena vaikutti olevan toisen osapuolen huvittaminen. Tulkitsimme ilmauksen huumorintajun osoittamiseksi puolestaan silloin, kun huumorin ilmaisija ei selvästikään alun perin ollut tarkoittanut ilmaustaan humoristiseksi, mutta vaihtoi puheenvuoronsa sävyä kesken lauseen. Tässä vaiheessa analysoimme aineistosta myös kaksi uutta huumorin vuorovaikutusfunktiota: ymmärryksen osoittamisen ja mielipiteen ilmaisemisen.

Vastaavasti esimerkiksi huumorityylien itseironia ja huumorin ilmaisijaa voimaannuttava huumori tulkintasääntöä tarkensimme siten, että määrittelimme itseironiaksi huumorin ilmaisijaan itseensä kohdistuvan pilkan tai naurunalaiseksi saattamisen. Huumorin ilmaisijaa voimauttavaksi huumoriksi määrittelimme sen sijaan sellaisen ilmauksen, joka ei ollut itseä vähättelevää, kuten itseironia. Viidennessä vaiheessa analysoimme aineiston kokonaisuudessaan ja merkitsimme havainnot havainnointitaulukkoon.

Analyysin viimeisessä vaiheessa laskimme absoluuttiset ja suhteelliset frekvenssit huumorin kielellisistä ja nonverbaalisista ilmaisutavoista, huumorityyleistä, huumorin vuorovaikutusfunktioista sekä huumorin ilmaisusta ja siihen reagoimisesta. Havainnollistamme tuloksia aineistoesimerkein, joihin työnohjaaja on merkitty lyhenteellä $\mathrm{TO}_{\mathrm{a}}$ tai $_{\mathrm{b}}$ ja ohjattava lyhenteellä $\mathrm{O}_{\mathrm{a}, \mathrm{b}}$ tai ${ }^{\text {. }}$

\section{Tulokset}

Huumorin kuvaamiseksi ja ymmärtämiseksi raportoimme tulokset seuraavanlaisesti: ensin tarkastelemme, millaista huumoria työnohjauksessa ilmenee ja miten siihen reagoidaan. Sen jälkeen kuvaamme, mitä vuorovaikutusfunktiota huumorilla työnohjauksessa on.

\section{Huumorin ilmaiseminen työnohjauksessa}

Analyysi osoittaa, että huumoria ilmaistaan työnohjauksessa verrattain paljon ja sitä ilmai- sevat sekä työnohjaajat että ohjattavat. Huumorin ilmaiseminen jakautuu työnohjauskeskusteluissa kuitenkin epätasaisesti työnohjaajien ja ohjattavien kesken. Kaikista keskustelujen sisältämistä huumorijaksoista suurin osa (72 \% eli yhteensä 73 huumorijaksoa) oli ohjattavien aloittamia. Työnohjaajat aloittivat huumorijakson yhteensä 29 kertaa (28 \% kaikista huumorijaksoista).

Huumoria ilmaistiin monin tavoin kielellisesti ja nonverbaalisesti. Pelkästään nonverbaalisesti huumoria ilmaistiin viidessä huumorijaksossa. Nonverbaalista huumoria ilmaistiin esimerkiksi äänensävyä muuttamalla, jolloin huumorin ilmaisija vahvisti kielellistä sanomaansa.

Työnohjaajien ja ohjattavien huumori on tyyliltään 1) vuorovaikutusosapuolia yhdistävää (53\%), 2) huumorin ilmaisijaa voimaannuttavaa (37\%), 3) itseironista (8 \%) ja 4) työnohjauksen toimintoihin ja työnohjaukseen tai työnohjaustilaan kohdistuvaa (2\% kaikista huumorijaksoista). Taulukko 2 osoittaa, miten työnohjaajat ja ohjattavat ilmaisivat huumoria.

Ohjattavien ilmaisema huumori oli tyyliltään pääasiassa heitä itseään voimauttavaa (49 \% kaikista heidän aloittamistaan huumorijaksoista) tai vuorovaikutusosapuolia yhdistävää (40 \% huumorijaksoista). Jonkin verran ilmeni myös itseironista huumoria (10 \%) tai työnohjaukseen kohdistuvaa huumoria (1\%). Työnohjaajat puolestaan ilmaisivat lähinnä vain vuorovaikutusosapuolia yhdistävää huumoria. Tyyliltään tällaista huumoria oli suurin osa (86 \%) kaikista heidän aloittamistaan huumorijaksoista. Työnohjaajien huumori-ilmauksista muutamat olivat myös heitä itseään voimaannuttavia (kaksi huumorijaksoa), itseironisia tai työohjaukseen kohdistuvia (molempia yksi huumorijakso).

Seuraavassa esimerkissä sekä työnohjaaja että ohjattava ilmaisevat huumoria vuorovaikutusosapuolia yhdistävästi. Esimerkissä ensin ohjattava ja sitten työnohjaaja aloittavat huumorijakson. Ohjattava kertoo siitä, miten hän on kotonaan puhunut työnohjauksen menetelmien auttavan häntä. Hän elehtii käsillään hu- 
TAULUKKO 2. Huumori-ilmausten tyylit työnohjauskeskusteluissa

\begin{tabular}{|l|c|c|}
\hline \multirow{2}{*}{ Huumori-ilmauksen tyyli } & \multicolumn{2}{|c|}{ Huumorin ilmaisija } \\
\cline { 2 - 3 } & Ohjattavat & Työnohjaajat \\
\hline Huumorin ilmaisijaa voimauttava & $36(49 \%)$ & $2(7 \%)$ \\
\hline Vuorovaikutusosapuolia yhdistävä & $29(40 \%)$ & $25(86 \%)$ \\
\hline Itseironia & $7(10 \%)$ & $1(3,5 \%)$ \\
\hline Työnohjaukseen kohdistuva & $1(1 \%)$ & $1(3,5 \%)$ \\
\hline Huumori-ilmauksia yhteensä & $73(100 \%)$ & $29(100 \%)$ \\
\hline
\end{tabular}

moristisesti (rivi 1), ja työnohjaaja reagoi tähän väliin nauramalla (rivi 2). Ohjattava jatkaa samaa huumorijaksoa imitoimalla humoristisesti itseään (rivillä 3). Työnohjaaja vastaa tähän hymyillen ja kielellisesti ja aloittaa sitten uuden huumorijakson elehtimällä käsillään viitaten humoristisesti sisäiseen parlamenttiin (rivit 4 ja 5). Ohjattava reagoi työnohjaajan huumoriin naurahtamalla ja ilmaisemalla samanmielisyyttä (rivillä 6).

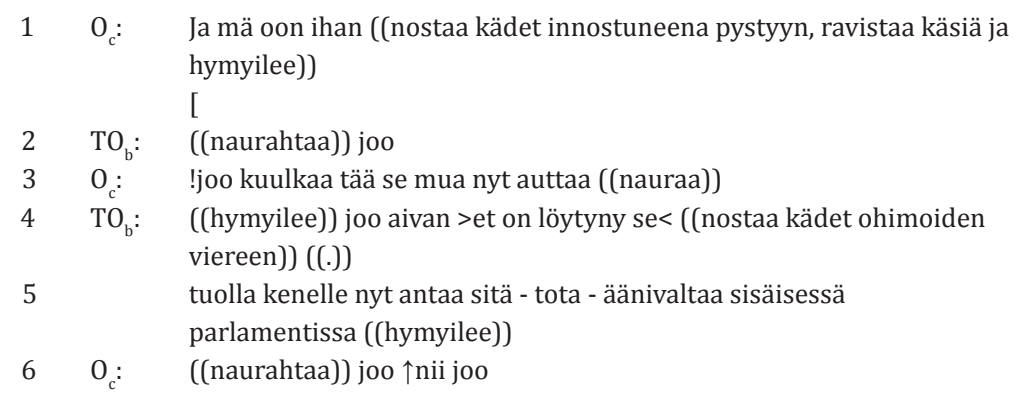

Työnohjauskeskusteluissa ilmeni myös ilmaisijaa voimauttavaa huumoria. Alla olevassa esimerkissä ohjattava kertoo työnohjaajalle puhelinkeskustelustaan läheisensä kanssa. Läheinen on puhelussaan ilmoittanut, että jos hän joutuu sairaalaan, hän haluaa ohjattavan tekevän hänelle "armomurhan". Ohjattava kertoo, miten tyynesti läheinen oli ilmaissut suunnitel- mansa (rivi 1). Työnohjaaja osoittaa kuuntelevansa (rivillä 2). Tämän jälkeen ohjattava levittää kätensä suurieleisesti hymyillen ja kertoo dramaattisesti liioitellen läheisensä "tilanneen murhan" (rivi 3). Työnohjaaja ei reagoi huvittuneesti, vaan katsoo muistiinpanojaan vakavana (rivi 4). Ohjattava vakavoituu ja jatkaa kertomustaan (rivi 5).

\footnotetext{
$1 \mathrm{O}_{\mathrm{a}}: \quad$-- ja ei se ollut siitä niiku mitenkään kiihtynyt tai muuta, hän oli tehnyt mielestään hyvän suunnitelman, se oli kauheen tyyni >ihan niiku< tilaisin suurin piirtein nyt uudet verhot ((.))

2 TO: Nii justii ja

$3 \quad 0_{a}: \quad$ ((levittää käsiään ja hymyilee) $) \uparrow n i i n$ tilaan murhan ((jää katsomaan työnohjaajaa hymyillen, kädet levällään))

$4 \quad \mathrm{TO}_{\mathrm{a}}$ : ((katsoo muistiinpanojaan) Nii justii. aivan

$5 \quad \mathrm{O}_{\mathrm{a}}: \quad$ ((vakavoituu)) Ei se niiku myöskää kysyny millää lailla --
} 
Huumori oli tyyliltään myös itseironista. Esimerkissä eräs ohjattavista kertoo siitä, miten ei ole saanut töissä palautetta. Hän aloittaa kertomalla "fiiliksistään" (rivit 1 ja 2) ja sitten nauramalla ja imitoimalla itseään kieltää ajattele- vansa, etteikö saisi myönteistä palautetta altistaen itsensä täten huumorin kohteeksi (rivillä 3). Lopuksi ohjattava vakavoituu ja jatkaa kertomustaan (rivit 4 ja 5).

\footnotetext{
$1 \quad \mathrm{O}_{\mathrm{b}}: \quad--$ ja tavallaan just se mä ite tunnistan sen $(()$.

$2 \quad \uparrow$ sen et se ei oo niinku sellanen oikeesti se mun fiilis ((.))

3 et mä miettisin ((naurahtaen)) !voi ei mä en saa täällä ikinä positiivista palautetta

4 ((käsillä elehtien)) > eikä se< et se hetki vaan oli sinällään, et se koko päivä oli niinku ((.))

5

((käsillä elehtien)) koko kymmenen tunnin päivä kiteyty siihen --
}

Työnohjaukseen kohdistuvaa, eli työnohjauksessa käytettäviin menetelmiin liittyvää huumoria ilmaistiin vähiten. Seuraavassa esimerkissä työnohjaaja siirtyy fläppitaululle piirtämään ohjattavasta havainnollistavaa kuvaa (rivit 1 ja 2). Ohjattava toteaa kertauksen olevan opintojen äiti (rivillä 3). Kun piirros on valmis, työnohjaaja hymähtää omalle tuotokselleen (rivi 6). Ohjattava reagoi tähän nauraen (rivillä 7), ja myös työnohjaaja yhtyy tähän (rivi 8), mikä osoittaa molempien osapuolien kokevan piirtämisen olevan huvittava tilanne.

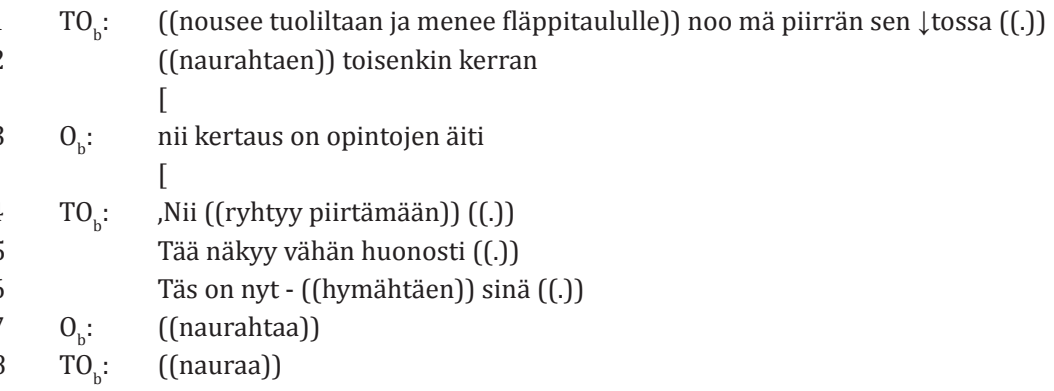

Työnohjaajat ja ohjattavat reagoivat toistensa joko nauramalla huvittuneesti tai hymyilemälilmaisemaan huumoriin eri tavoin. Taulukosta 3 ilmenee se, missä määrin vuorovaikutusosapuoli reagoi toisen ilmaisemaan huumoriin lä. Osa huumori-ilmauksista jäi yksipuolisiksi eli toinen osapuoli ei ilmaissut huvittuneisuutta, mikä on tässä merkitty "ei reaktiota".

TAULUKKO 3. Reagoiminen työnohjausosapuolen ilmaisemaan huumoriin

\begin{tabular}{|l|c|c|}
\hline $\begin{array}{l}\text { Työnohjausosapuolen reagoiminen toisen } \\
\text { huumori-ilmaisuun }\end{array}$ & $\begin{array}{c}\text { Työnohjaaja reagoi } \\
\text { ohjattavan } \\
\text { huumori-ilmaukseen }\end{array}$ & $\begin{array}{c}\text { Ohjattava reagoi } \\
\text { työnohjaajan } \\
\text { huumori-ilmaukseen }\end{array}$ \\
\hline Kyllä & $37(51 \%)$ & $25(86 \%)$ \\
\hline Ei & $36(49 \%)$ & $4(14 \%)$ \\
\hline Yhteensä & $73(100 \%)$ & $29(100 \%)$ \\
\hline
\end{tabular}


Tulokset osoittavat, että ohjattavat reagoivat nauramalla tai hymyilemällä työnohjaajansa huumori-ilmaukseen liki poikkeuksetta (yhteensä $86 \%$ kaikista huumori-ilmauksista), kun taas työnohjaajat reagoivat tai olivat reagoimatta ohjattavansa huumori-ilmaukseen suurin piirtein yhtä usein.

\section{Huumorin vuorovaikutusfunktiot työnohjauksessa}

Huumori toteutti työnohjauksessa useita erilaisia vuorovaikutusfunktioita. Näitä olivat kuormituksen hallitseminen, välittömyyden ilmaiseminen, itsensä ilmaiseminen, vuorovaikutussuhteen rakenteiden näkyväksi tekeminen ja kolmannen osapuolen vähättely. Tulokset siitä, mitä vuorovaikutusfunktioita huumori työnohjauksessa toteuttaa, on esitetty taulukossa 4.

Huumori näyttäisi liittyvän työnohjauksessa lähinnä sellaisiin tilanteisiin, joissa huumo- rin ilmaisija, vuorovaikutusosapuoli tai molemmat kokevat epävarmuutta ja kuormitusta. Huumori liittyy tällöin tarpeeseen hallita arkaluontoisten asioiden käsittelyn aiheuttamaa kuormitusta (33 \% kaikista huumorijaksoista) tai uuden keskusteluaiheen aiheuttamaa jännittyneisyyttä $(4,9 \%)$.

Seuraavassa esimerkissä huumorilla oli arkaluontoisen asian hallitsemisen funktio. Ohjattava on ottanut keskustelussa jo aiemmin esiin arkaluonteisen asian ja kertoo sitten, kuinka vaikea puhelu läheisen kanssa alkoi. Ohjattava on todennut hermostuvansa huomatessaan kyseisen läheisen nimen puhelimen näytöllä, ja jatkaa tarkentavalla tarinalla siitä, mitä eräänä päivänä puhelimen soidessa tapahtui. Hän ilmaisee huumoria hymyillen ja elehtien todetessaan, että puhelinkeskustelu sujui siihen saakka hyvin (rivi 5). Ohjaaja reagoi tähän hymyilemällä (rivi 6).

TAULUKKO 4. Huumorin vuorovaikutusfunktiot työnohjauksessa

\begin{tabular}{|c|c|c|}
\hline Vuorovaikutusfunktio & f & $\%$ \\
\hline $\begin{array}{l}\text { Kuormituksen hallitseminen } \\
\text { - arkaluontoisen asian hallitseminen } \\
\text { - uuden aiheen tuoman jännittyneisyyden vähentäminen } \\
\text { Kuormituksen hallitsemiseen liittyvät yhteensä }\end{array}$ & $\begin{array}{r}34 \\
5 \\
39\end{array}$ & $\begin{array}{r}33,33 \\
4,9 \\
38,23\end{array}$ \\
\hline $\begin{array}{l}\text { Välittömyyden ilmaiseminen } \\
\text { - vuorovaikutusosapuolen viihdyttäminen } \\
\text { - vuorovaikutusosapuolen rohkaiseminen } \\
\text { - leikkimielisyyden ilmaiseminen } \\
\text { Välittömyyden ilmaisemiseen liittyvät yhteensä }\end{array}$ & $\begin{array}{r}16 \\
15 \\
1 \\
32\end{array}$ & $\begin{array}{r}15,69 \\
14,71 \\
0,98 \\
31,38\end{array}$ \\
\hline $\begin{array}{l}\text { Itsensä ilmaiseminen } \\
\text { - omien tunteiden ilmaiseminen } \\
\text { - huumorintajun osoittaminen } \\
\text { - mielipiteen ilmaiseminen } \\
\text { - toisen ymmärtämisen osoittaminen } \\
\text { - omien mieltymysten ilmaiseminen } \\
\text { - myönteisen vaikutelman luominen itsestä } \\
\text { Itsensä ilmaisemiseen liittyvät yhteensä }\end{array}$ & $\begin{array}{r}10 \\
6 \\
4 \\
3 \\
2 \\
1 \\
25\end{array}$ & $\begin{array}{r}9,8 \\
5,88 \\
3,92 \\
2,94 \\
1,96 \\
0,98 \\
25,48\end{array}$ \\
\hline Vuorovaikutussuhteen rakenteiden näkyväksi tekeminen & 3 & 2,94 \\
\hline Kolmannen osapuolen vähättely & 2 & 1,96 \\
\hline Huumorijaksoja yhteensä & 102 & 100,0 \\
\hline
\end{tabular}




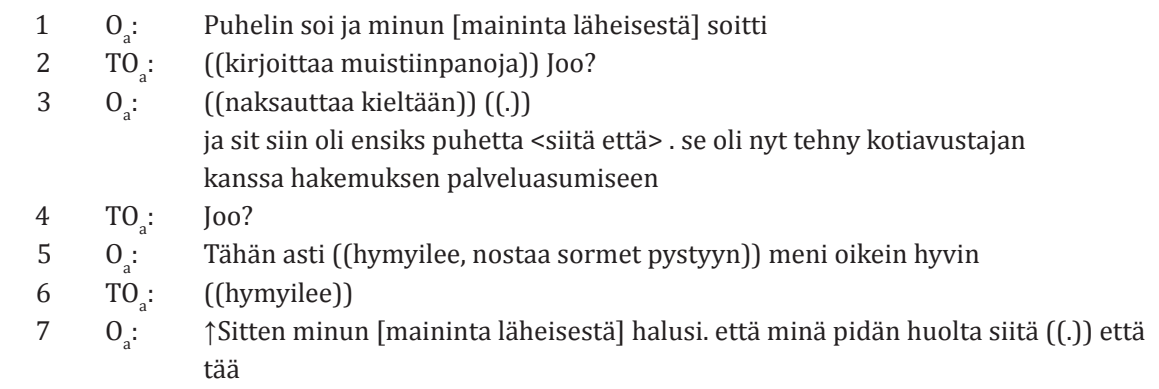

Huumoria työnohjauskeskusteluissa ilmeni myös silloin, kun toinen vuorovaikutusosapuoli vaihtoi puheenaihetta, nosti esiin kokonaan uuden asian tai toi uutta tietoa. Tällöin huumorilla on uuden aiheen tuoman jännittyneisyyden $v a ̈ h e n t a ̈ m i s e n$ funktio. Seuraavassa esimerkissä työnohjaaja ryhtyy kertaamaan aiemmin ta- paamisessa käytyä keskustelua ohjattavan väsymyksestä ja naurahtaa (rivi 1). Ohjattava reagoi tähän puheenaiheen vaihtoon viittaamalla humoristisesti tarpeeseensa puhua asiasta ja elehtii käsillään (rivit 2 ja 4). Työnohjaaja nauraa (rivi 3) ja jatkaa sitten vakavoituneena alaistaidoista (rivillä 5).

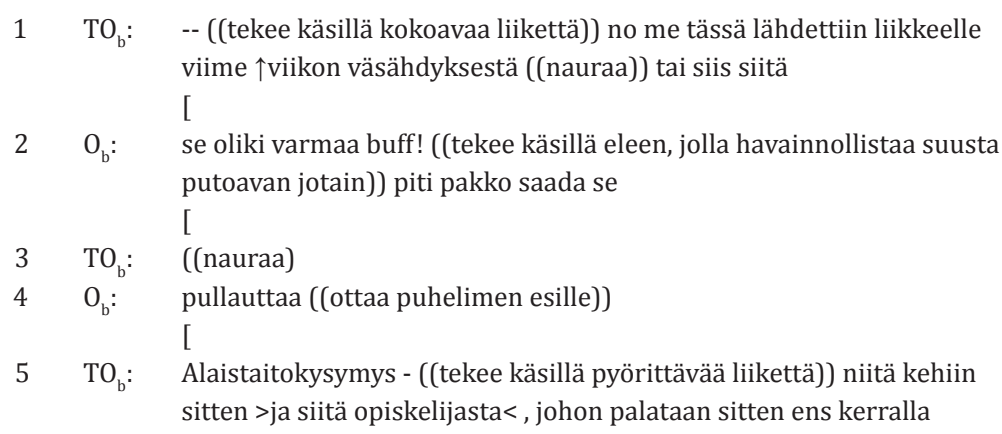

Huumori liittyi työnohjauksessa myös tarpeeseen ilmaista arvostusta, välittämistä ja välittömyyttä toista osapuolta kohtaan. Tällaisia huumorijaksoja oli liki kolmasosa (31 \%) kaikista huumorijaksoista. Välittömyys ilmeni huumorina, joka kohdistui toisen viihdyttämiseen ja rohkaisemiseen tai joka osoitti omaa leikkimielisyyttä. Seuraavassa esimerkissä huumorilla on vuorovaikutusosapuolen viihdyttämi- sen funktio. Työnohjaaja kehottaa ohjattavaa uskaltamaan ilmaista omia mielipiteitään työpaikan keskusteluissa (rivi 1). Ohjattava reagoi ensin hymyilemällä ja ilmaisee humoristisesti elehtien ja nauraen, miten todellakin voisi keskeyttää toiset ja saada puheenvuoron itselleen (rivi 2). Työnohjaaja reagoi jatkamalla ohjattavan dramatisoivaa puheenvuoroa samaan liioittelevaan tyyliin (rivi 3).

$1 \quad \mathrm{TO}_{\mathrm{b}}$ : Et uskaltaa vaa ((tekee kädellään leikkaavaa liikettä))

[

$2 \quad \mathrm{O}_{\mathrm{b}}: \quad$ ((hymyilee)) Nii et nyt - nyt puheenvuorot seis ((tekee kädellään väliin tulevan liikkeen)) >mun pitää ((naurahtaen)) vähä hihkasta tässä ((nauraa))

$3 \mathrm{TO}_{\mathrm{b}}$ : Joo - et mietitääs nyt et mitä me tässä tuli sanotuks [

$4 \quad \mathrm{O}_{\mathrm{b}}: \quad$ Joo 
Työnohjauksessa pyrittiin huumorin avulla rohkaisemaan vuorovaikutusosapuolta. Tällöin huumorilla saatettiin osoittaa hyväksyntää toisen kuormitukselle. Seuraavassa esimerkissä huumorilla on vuorovaikutusosapuolen rohkaisemisen funktio. Osapuolet ovat keskustelleet siitä, miten ohjattava voisi ottaa puheeksi kollegojensa kanssa ammattinimikkeisiin kuuluvat työtehtävät. Työnohjaaja viittaa (rivillä 1) humoristisesti ohjattavan "ystävällisen ihmettelijän roolikuvaan" ja näin rohkaisee ohjattavaa ottamaan asian puheeksi. Ohjattavaa tämä työnohjaajan sanavalinta näyttää huvittavan, ja hän ilmaisee huvittuneisuuttaan nauramalla (rivi 2). Osapuolet jatkavat nauramalla yhdessä ja hymyilemällä kyseisen "roolikuvan" toteuttamiselle (rivit 3-5).

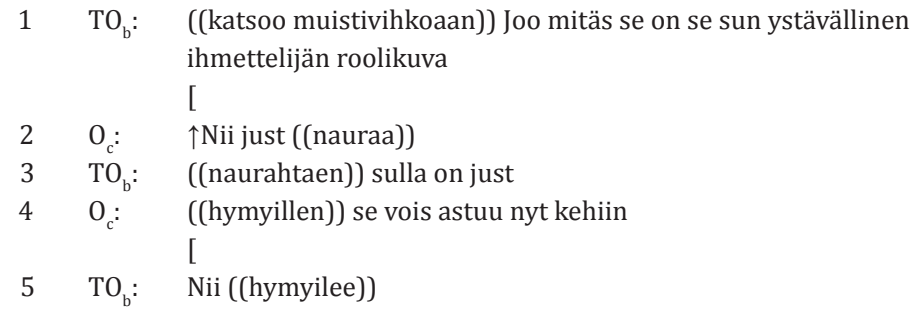

Sekä työnohjaajien että ohjattavien huumori näytti toteuttavan itseilmaisun tarvetta. Ohjauskeskusteluissa ilmaistiin humoristisesti omia tunteita, mielipiteitä ja mieltymyksiä sekä omaa huumorintajua tai pyrittiin luomaan myönteistä vaikutelmaa itsestä. Huumorijaksoista tällaisia oli neljäsosa (25 \%).

Omien tunteiden ilmaisemisen vuorovaikutusfunktio ilmeni työnohjauksessa silloin, kun huumorin ilmaisija toi esiin joko senhetkisiä tai menneitä tunteitaan tai mielialaansa. Seuraavassa esimerkissä ohjattava kertoo puhelinkeskustelustaan läheisensä kanssa.
Ohjattava aloittaa kertomalla, että hänen läheisensä on kieltänyt puhuneensa yhteisistä asioista muille (rivi 1). Työnohjaaja hymyilee (rivillä 2), ja ohjattava toteaa elehtien läheisen sanoneen hänen kohdelleen tätä huonosti (rivi 3). Heti tämän jälkeen ohjattava osoittaa turhautumistaan läheisensä käyttäytymistä kohtaan ilmaisemalla huumoria nonverbaalisesti pärisyttämällä huuliaan äänekkäästi, nojautumalla suurieleisesti taaksepäin ja siirtämällä katseensa kattoon. Työnohjaaja reagoi nauramalla (rivi 4).

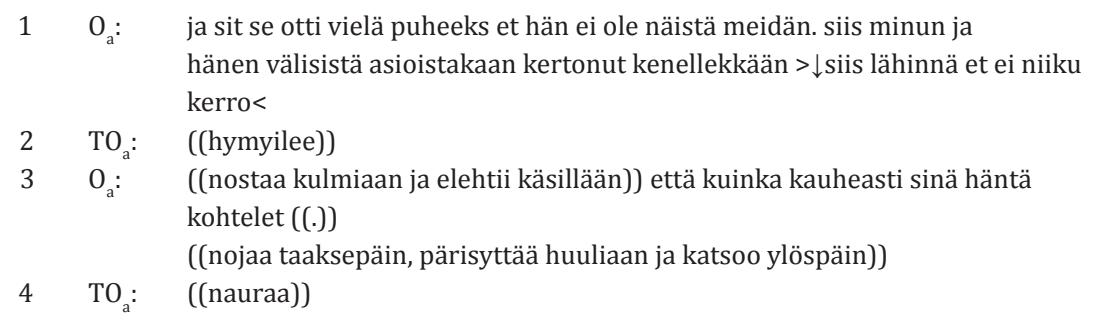

Huumorintajun osoittamisen vuorovaikutusfunktiota oli havaittavissa silloin, kun huumorin ilmaisija vaihtoi ilmaisutyylinsä yllättäen kesken puheenvuoron huomattuaan sanomansa sisältävän humoristisia aineksia. Alla olevassa esimerkissä työnohjaaja ja ohjattava keskus- televat päiväkodin ryhmäjaosta. Ohjattava aloittaa kertomalla ryhmäjaoista (rivi 1), ja työnohjaaja ilmaisee kuuntelevansa (rivi 2). Ohjattava muistelee vanhoja nimityskäytänteitä (rivi 3), alkaa luetella erilaisia ryhmänimiä sormillaan elehtien ja purskahtaa nauruun kerrottuaan 
kaksi ensimmäistä nimeä (rivi 4) ja työnohjaaja reagoi nauramalla (rivillä 5) ohjattavan jatkaessa nauraen luettelemista (rivi 6).

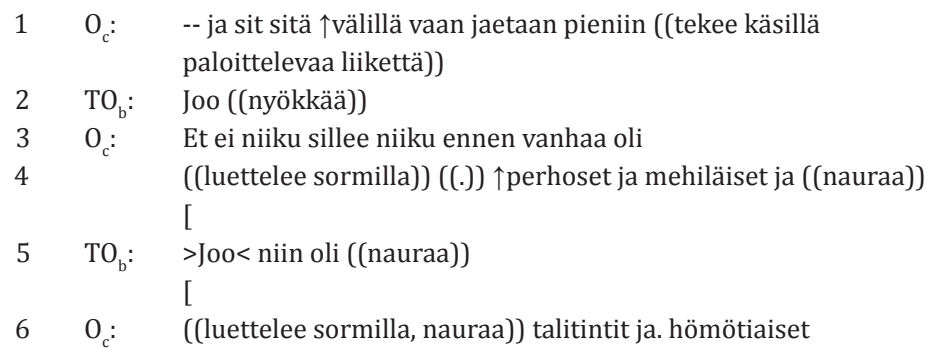

Ohjauskeskusteluissa huumori ilmensi myös vuorovaikutussuhteen rakenteita (3 huumorijaksoa). Tämä ilmeni esimerkiksi työnohjaajan asiantuntijavallan näkyväksi tekemisenä. Huumorilla näytti olleen myös kolmatta osapuolta vähättelevä vuorovaikutusfunktio (2 huumorijaksoa). Tällainen huumori vaikutti yhdistävän vuorovaikutusosapuolia.

\section{Pohdinta ja johtopäätökset}

Analysoiduissa ohjauskeskusteluissa ilmeni paljon huumoria. Sen ilmaiseminen jakautui työnohjaajan ja ohjattavan kesken kuitenkin epätasaisesti: ohjattava ilmaisi huumoria huomattavasti enemmän kuin työnohjaaja. Tämä epäsuhta on odotusten mukaista ammatillisessa vuorovaikutussuhteessa. Suhteen osapuolilla voi olla erilaista ammatillista osaamista, ja tieto voi olla epätasaisesti jakautunut osapuolten kesken, mikä voi vaikuttaa osapuolten tapaan viestiä suhteessaan (Puutio ym. 2008, 35). Esimerkiksi naurua koskevissa tutkimuksissa on havaittu potilaan nauravan vastaanotolla enemmän kuin häntä tutkiva lääkäri (Haakana 2001). Ohjattavalla on enemmän mahdollisuuksia ja tarvettakin ilmaista huumoria, koska työnohjauksessa käsitellään juuri hänen asioitaan. Ohjattava on ohjaustapaamisissa useimmiten enemmän äänessä. Vastaavasti työnohjaajan on osoitettava arvostusta ja ymmärrystä ohjattavaa ja hänen kokemuksiaan kohtaan sekä ylläpidettävä vuorovaikutussuhteen ammattimaisuutta, jolloin huumorin ilmaiseminen ei ole välttämättä aina tarkoituksenmukaista.

Huumoria ilmaistiin työnohjauksessa useimmiten vuorovaikutusosapuolia yhdistävällä tai huumorin ilmaisijaa voimauttavalla tyylillä. Itseironiaa ja työnohjaukseen kohdistuvaa huumoria ilmeni myös hieman. Huumori voi siis työnohjauksessa edistää vuorovaikutustilanteen avointa ja luottamuksellista ilmapiiriä sekä auttaa löytämään uusia näkökulmia ongelmiin, mikä on havaittu myös muissa ammatillisissa vuorovaikutussuhteissa (ks. esim. Gladding 1995; Goodboyn ym. 2015; Maples ym. 2001; Scholl 2007; Simmons-Mackie \& Schultz 2003).

Työnohjaajien ja ohjattavien huumori-ilmaisut erosivat tyyliltään jonkin verran, mikä johtuu osapuolten erilaisista rooleista tämänkaltaisessa ammatillisessa vuorovaikutussuhteessa. Työnohjaajien huumori oli tulkittavissa lähes poikkeuksetta vuorovaikutusosapuolia yhdistäväksi. Tämä onkin luontevaa, koska työnohjaajalla on ohjauksessa asiantuntijarooli. Hänellä on vastuu ohjaussuhteen ylläpidosta ja ohjaustavoitteiden saavuttamisesta. Asiantuntijan odotetaan vastaavan nimenomaan asiakkaan emotionaalisiin tarpeisiin (Gerlander \& Isotalus 2010, 10).

Toisaalta myös ohjattavat ilmaisevat huumoria runsaasti vuorovaikutusosapuolia yhdistävästi, vaikka ohjattavalla ei ole työnohjaajan kaltaista vastuuta ylläpitää ja sujuvoittaa 
vuorovaikutusta. Tämä kuvastaa työnohjauksen erityisluonnetta: ohjattava voi pyrkiä omalta osaltaan aktiivisesti rakentamaan vuorovaikutussuhdetta sellaiseksi, että siinä on helppoa ilmaista ja käsitellä vaikeitakin asioita. Tämänkaltainen huumori voi lisätä myös vuorovaikutusosapuolten välistä luottamusta.

Ohjattavat ilmaisivat huumoria itseä voimauttavalla tyylillä, mikä on työnohjauksen luonteen mukaista. Ohjauksessa käsitellään ohjattavan henkilökohtaisia ja usein hyvinkin kuormittavia asioita. Huumori toimii tällöin kuormittuneisuutta vähentävänä tekijänä.

Tulokset huumorin vuorovaikutusfunktioista vahvistavat saman asian, minkä huumorityylien analyysi osoitti. Huumori näyttää työohjauskeskustelussa olevan keino hallita kuormittuneisuutta ja käsitellä arkaluoteisiin asioihin liittyviä tunteita. Huumoria ilmaisemalla vuorovaikutusosapuolet voivat ottaa puheeksi vaikeita, jopa normien vastaisia asioita hyväksyttävällä tavalla. Vaikean asian ääneen sanominen lieventää sitä kuormitusta, jota tunteiden kätkeminen aiheuttaa, jolloin vaikeistakin asioista voidaan jatkossa puhua vapaammin (Foot \& McCreaddie 2006, 298; Haakana 2001, 150-153). Työnohjauksessa huumorilla on tärkeä tehtävä juuri ohjattavan voimavarojen kannalta.

Huumori tukee työnohjauksessa tunteiden ja mielipiteiden ilmaisua. Työnohjaajan ja ohjattavan vuorovaikutuksessa tasapainoillaan suhteen etäisyyden ja läheisyyden jännitteen varassa. Etäisyyden ylläpitäminen on tärkeää työnohjaajan ammatillisen objektiivisuuden säilyttämiseksi ja toisaalta myös ohjattavan autonomian ylläpidon kannalta. Läheisyyttäkin tarvitaan, jotta asioista voidaan puhua riittävän avoimesti. Huumorin avulla osapuolet voivat hallita epävarmuuttaan siitä, miten toinen reagoi toisen ilmaisuun. Huumori toimii siis viestintää pehmentävänä tekijänä. Sen avulla on mahdollista ilmaista asioita hienovaraisesti. Työnohjauksessa huumori voi kytkeytyä myös henkilövaikutelmien hallintaan eli siihen, millaisen kuvan osapuolet haluavat toisille antaa. Kyseessä on vaikuttamisen muoto, jolla ylläpidetään itsetuntoa, vältetään kielteisiä tunteita ja rakennetaan henkilökohtaista identiteettiä (Kim 2008).

Huumori paljastaa työnohjaajan ja ohjattavan vuorovaikutussuhteen rakenteita. Työnohjaaja ja ohjattava näyttävät arvioivan ja vahvistavan vuorovaikutuskäytänteitään ja ylläpitävän vuorovaikutussuhteen ammattimaisuutta huumorin avulla. Huumori viestii työnohjaajan asiantuntijaroolista ja ilmaisee esimerkiksi sen, miten etäiseksi tai läheiseksi osapuolet suhteensa määrittelevät. Huumori auttaa työnohjaajaa ja ohjattavaa hahmottamaan roolejaan ja vuorovaikutussuhdettaan sekä saavuttamaan työnohjauksen tavoitteita.

Tulokset kuvaavat huumorin tyyliä ja merkitystä työnohjauskeskustelussa, mitä tästä näkökulmasta ei aiemmin ole tutkittu. Tulosten vahvistettavuutta lisää se, että sekä huumorityylejä että huumorin vuorovaikutusfunktioita koskevat tulokset ovat samansuuntaisia sen suhteen, millaisena työnohjausvuorovaikutus ja suhteen ominaislaatu näyttäytyvät. Tulokset siitä, millaista huumori on muissa ammatillisissa vuorovaikutussuhteissa vahvistavat myös tämän tutkimuksen tuloksia (esim. Bolkan \& Goodboy 2015; Scholl 2007; Simmons-Mackie \& Schultz 2003). Toisaalta tuloksia puntaroidessa on tärkeää ottaa huomioon aineiston rajallisuus. Se koostuu vain kolmesta työnohjauskeskustelusta. On siis mahdoton arvioida, missä määrin muissa työnohjauksissa ilmenee samanlaista huumoria.

\section{Lopuksi}

Huumorin hyötyjä auttamistyössä on alettu ymmärtää entistä paremmin. Huumori voidaan nähdä hyödyllisenä esimerkiksi asiakkaan itsetietoisuuden lisäämisessä (Foot \& McCreaddie 2006, 312). Työnohjauksessa huumori näyttää edistävän vuorovaikutusta ja vuorovaikutussuhdetta. Huumori ilmentää ja auttaa hallitsemaan ohjauksessa käsiteltäviä, kuormittavia asioita, minkä voidaan ajatella edistävän 
ohjattavan itsetietoisuutta. Lisäksi huumorin avulla pyritään hallitsemaan jännittyneisyyttä. Huumorilla on täten merkittävä rooli ohjauksen tavoitteiden saavuttamisen kannalta. Tämä edellyttää kuitenkin työnohjaajalta herkkyyttä havaita ja tulkita ohjattavan huumoria, jotta hän voisi tukea esimerkiksi ohjattavan kasvojen säilyttämistä ja ohjauskeskustelun jatkumista.

Tässä tutkimuksessa työnohjaustilanteen huumoria tarkasteltiin videotallenteiden perusteella. On vaikea tietää, missä määrin ohjauskeskusteluissa ilmennyt huumori oli seurausta kameran ja tutkijan katseen alle joutumisesta ja tästä johtuvasta kuormittuneisuudesta. Havaittuja tuloksia voitaisiin jatkossa varmentaa ja syventää tekemällä jälkihaastatteluita. Työnohjauksen osapuolilta voisi tällöin kysyä, mikä heissä herätti huvittuneisuutta ja miten he huumoria itse tulkitsisivat. Huumoria voisi tutkia myös ryhmätyönohjauksessa. Ryhmässä on samanaikaisesti useita erilaisia vuorovaikutussuhteita, jotka heijastuvat vuorovaikutuksessa ilmeneviin

\section{Kirjallisuus}

Alhanen, K., Kansanaho, A., Ahtiainen, O-P., Kangas, M., Soini, T. \& Soininen, J. (2016) Työnohjauksen käsikirja. Helsinki: BoD.

Baxter, L. A. \& Montgomery, B. M. (1996) Relating dialogues and dialectics. New York: Guilford Press.

Baxter, L. A. \& Norwood, K. M. (2015) Relational dialectics theory. Navigating meaning from competing discourses. Teoksessa D. O. Braithwaite \& P. Schrodt (toim.) Engaging theories in interpersonal communication. Multiple perspectives. 2. painos. Los Angeles: Sage, 279-291.

Bolkan, S. \& Goodboy A. K. (2015) Exploratory theoretical tests of the instructor humor-student learning link. Communication Education 61 (1), 45-64.

Dziegielewski, S., Jacinto, G., Laudadio, A. \& Legg-Rodriguez, L. (2003) Humor: an essential communication tool in therapy. International Journal of Mental Health 32 (3), 74-90. jännitteisiin ja niiden hallintaan. Näin ollen myös huumoria saatetaan ilmaista eri tavalla ja sillä voi olla toisenlaisia vuorovaikutusfunktioita kuin yksilötyönohjauksessa.

Tutkimuksemme tulokset auttavat ymmärtämään yksilötyönohjauksen vuorovaikutusta ja siinä ilmenevän huumorin merkitystä erityisesti ohjaussuhteen ja ohjausvuorovaikutuksen luonteen sekä ohjauksen onnistumisen kannalta. Parhaimmillaan huumori edistää merkittävästi koko ohjausprosessia.

\section{Kirjoittajat}

Elina Heininen, FM, viestintä- ja tapahtumavastaava, Sauna from Finland ry, sähköposti: elinahenriikkaheininen@hotmail.com

Sakari Siilin, FM, yrittäjä, Byway

Communications $\mathrm{Oy}$,

sähköposti: sakke.siilin@gmail.com

Tarja Valkonen, FT, lehtori, Jyväskylän yliopisto, sähköposti: tarja.valkonen@jyu.fi

Foot, H. \& McCreaddie, M. (2006) Humour and laughter. Teoksessa O. Hargie (toim.) Handbook of communication skills. New York: Routledge, 293-322

Frey, L. R., Botan, C. H. \& Kreps, G. L. (2000) Investigating communication: an introduction to research methods. 2. painos. Boston: Allyn and Bacon.

Gerlander, M. \& Isotalus, P. (2010) Professionaalisten viestintäsuhteiden ääriviivoja. Puhe ja kieli 30 (1), 3-19.

Gladding, S. T. (1995) Humor in counseling: using a natural resource. Journal of Humanistic Education and Development 34 (1), 1-10.

Gladding, T. \& Drake Wallace, J. (2016) Promoting beneficial humor in counseling: a way of helping counselors help clients. Journal of Creativity in Mental Health 11 (1), 2-11.

Goodboy, A., Booth-Butterfield, M., Bolkan, S. \& Griffin D. J. (2015) The role of instructor humor and 
students' educational orientations in student learning, extra effort, participation, and out-ofclass communication. Communication Quarterly 64 (1), 44-61.

Graham, E. E., Papa, M. J. \& Brooks, G. P. (1992) Functions of humor in conversation: conceptualization and measurement. Western Journal of Communication 56 (2), 161-183.

Guerrero, L. K., Andersen, P. A. \& Afifi, W. A. (2011) Close encounters: Communication in relationships. 3. painos. Thousand Oaks: Sage.

Haakana, M. (2001) Lääkäri, potilas ja nauru. Teoksessa M-L. Sorjonen, A. Peräkylä \& K. Eskola (toim.) Keskustelu lääkärin vastaanotolla. Tampere: Vastapaino, 135-160.

Holmes, J. (2000) Politeness, power and provocation: How humour functions in the work-place. Discourse Studies 2 (2), 159-185.

Holmes, J. (2006) Sharing a laugh: Pragmatic aspects of humor and gender in the workplace. Journal of Pragmatics 38 (1), 26-50.

Kangasharju, H. \& Nikko, T. (2009) Motions in organizations: Joint laughter in workplace meetings. Journal of Business Communication 46 (1), 100-119.

Kankaanranta, R. (2008) Mihin työnohjaus perustuu ja minkälaisia vaikutuksia sillä on? Teoksessa S. Keskinen (toim.) Työnohjaus: Mitä, missä, milloin? Turku: Turun yliopiston täydennyskoulutuskeskus, 13-28.

Kim, E. J. (2008) Impression management. Teoksessa W. Donsbach (toim.) The international encyclopedia of communication. London: Blackwell. [online] <URL:https://doi. org/10.1002/9781405186407.wbieci013>. Luettu: 17.1.2019.

Lynch O. H. (2002) Humorous communication: finding a place for humor in communication research. Communication Theory 12 (4), 423-445.

Lynch, O. H. (2009) Humorous communication theory. Teoksessa K. A. Foss \& S. W. Littlejohn (toim.) Encyclopedia of communication theory. Thousand Oaks: Sage, 480-483.

Maples, M. F., Dupey, P., Torres-Rivera, E., Phan, L. T., Vereen, L. \& Garrett, M. T. (2001) Ethnic diversity and the use of humor in counseling: appropriate or inappropriate? Journal of Counseling \& Development 79 (1), 53-60.

Myers, R. A. \& Seibold, D. R. (2012) Coding group interaction. Teoksessa A. B. Hollingshead \& M. S. Poole (toim.) Research methods for studying groups and teams: a guide to approaches, tools, and technologies. New York: Routledge, 329-357.

Paunonen-Ilmonen, M. (2001) Työnohjaus: Toiminnan laadunhallinnan varmistaja. Helsinki: WSOY.

Puutio, R., Kykyri, V-L. \& Wahlström, J. (2008) Constructing asymmetry and symmetry in relationships within a consulting system. Systemic Practice and Action Research 21 (1), 35-54.

Romero, E. J. \& Cruthirds, K. W. (2006) The use of humor in the workplace. Academy of Management Perspectives 20 (2), 58-69.

Samson, C. \& Gross, J. (2012) Humour as emotion regulation: The differential consequences of negative versus positive humour. Cognition and Emotion 26 (2), 375-384.

Scholl, J. C. (2007) The use of humour to promote patient-centered care. Journal of Applied Communication Research 35 (2), 156-176.

Sias, P. M. (2009) Organizing relationships: Traditional and emerging perspectives on workplace relationships. Thousand Oaks: Sage.

Simmons-Mackie, N. \& Schultz, M. (2003) The role of humor in therapy for aphasia. Aphasiology 17 (8), 751-766.

Työnohjaus. (2019) Suomen Työnohjaajat ry. [online]. <URL:http://www.suomentyonohjaajat.fi/ tyonohjaus>. Luettu 14.3.2019.

Vehviläinen, S. (2000) Keskusteluanalyysia ohjausvuorovaikutuksesta. Esimerkkinä opiskelijan huolten käsittely. Teoksessa J. Onnismaa, H. Pasanen \& T. Spangar (toim.) Ohjaus ammattina ja tieteenalana 1. Jyväskylä: PS-Kustannus, 221-251.

Vuorela, T. (2005) Laughing matters: A case study of humor in multicultural business negotiations. Negotiation Journal 21 (1), 105-130.

Wanzer, M. B., Frymier A. B. \& Irwin, J. (2010) An explanation of the relationship between instructor humor and student learning: instructional humor processing theory. Communication Education 59 (1), 1-18. 